Economics Development Analysis Journal 7 (4) (2018)

\title{
Analisis Pola Rantai Distribusi Alternatif Perikanan Tangkap di Kabupaten Kendal
}

\author{
Assafrul Ali Adhim ${ }^{1 凶}$, Etty Soesilowati ${ }^{2}$ \\ Jurusan Ekonomi Pembangunan, Fakultas Ekonomi, Universitas Negeri Semarang
}

\begin{tabular}{|c|c|}
\hline Info Artikel & Abstrak \\
\hline $\begin{array}{l}\text { Sejarah Artikel: } \\
\text { Diterima Juli } 2018 \\
\text { Disetujui September } 2018 \\
\text { Dipublikasikan } \\
\text { November } 2018\end{array}$ & $\begin{array}{l}\text { Tujuan penelitian ini untuk mengetahui pola rantai distribusi perikanan, margin keuntungan setiap } \\
\text { pelaku tata niaga perikanan, dan mencarikan model distribusi alternatif untuk perikanan tangkap } \\
\text { laut di Kabupaten Kendal. Metode yang digunakan yaitu pendekatan deskriptif kuantitatif guna } \\
\text { untuk mengetahui pola rantai distribusi perikanan, margin pemasaran, dan penentuan model } \\
\text { distribusi alternatif. Jenis data yaitu data sekunder, dan data primer yang di ambil langsung dari } 93 \\
\text { nelayan, } 50 \text { pedagang pengecer, } 35 \text { pedagang sedang, dan } 10 \text { pedagang besar. Teknik pengumpulan }\end{array}$ \\
\hline $\begin{array}{l}\text { Keywords: } \\
\text { Motor Vehicle Tax, } \\
\text { Earmarked Tax Policy, } \\
\text { Public Service. }\end{array}$ & $\begin{array}{l}\text { data yang digunakan yaitu interview, kuesioner, observasi, dan studi pustaka. Hasil dalam penelitian } \\
\text { ini yaitu sekurang-kurangnya terdapat tiga pola distribusi namun hanya ada dua pola yang paling } \\
\text { dominan yaitu pola pertama: nelayan ke pedagang sedang ke pedagang besar ke pabrik atau pasar } \\
\text { tradisional. Pola yang kedua yaitu nelayan ke pedagang sedang ke pedagang pengecer ke konsumen } \\
\text { akhir. Margin pemasaran untuk Cumi-cumi tertinggi terjadi pada pedagang besar }(21 \%) \text {, Pedagang } \\
\text { sedang }(8,6 \%) \text {, dan pedagang pengecer }(5,7 \%) \text {. Udang tertinggi pada pedagang besar }(13,7 \%) \text {, } \\
\text { pedagang sedang ( } 5 \%) \text {, pedagang pengecer }(3,9 \%) \text {. Ikan Kembung tertinggi pada pedagang besar } \\
(31 \%) \text {, pedagang pengecer }(11 \%) \text {, pedagang sedang }(9 \%) \text {. }\end{array}$ \\
\hline
\end{tabular}

\section{Abstract}

The purpose of this research is to know the pattern of fishery distribution chain, profit margin of every fishery trading actors, and to find alternative distribution model for marine catch fishery in Kendal Regency. The method used is quantitative descriptive approach in order to know the pattern of fishery distribution chain, marketing margin, and the determination of alternative distribution model. The types of data are secondary data, and primary data taken directly from 93 fishermen, 50 retailers, 35 medium traders, and 10 wholesalers. Data collection techniques used were interview, questionnaire, observation, and literature study. The result of this research is that there are at least three distribution patterns but there are only two most dominant patterns, namely the first pattern: fishermen to medium traders to wholesalers to factories or traditional markets. The second pattern is the fisherman to the merchant is to the retailer to the end consumer. The highest marketing margin for Squid occurred in wholesalers (21\%), Traders (8.6\%), and retailers (5.7\%). The highest shrimp on wholesalers (13.7\%), medium traders (5\%), retailers (3.9\%). The highest stocks were in big traders (31\%), retailers (11\%), traders (9\%).

\footnotetext{
${ }^{凶}$ Alamat korespondensi:

Gedung L2 Lantai 2 FE Unnes

Kampus Sekaran, Gunungpati, Semarang, 50229

E-mail: edajunnes@yahoo.com
} ISSN 2252-6965 


\section{PENDAHULUAN}

Perikanan merupakan kegiatan yang berhubungan dengan pengelolaan dan pemanfaatan sumber daya laut dan lingkungan mulai dari praproduksi, produksi, pengolahan sampai dengan pemasaran yang dilaksanakan dalam suatu sistem bisnis perikanan. Indonesia sebagai negara yang dua per tiga terdiri dari laut maka dari itu hal yang sangat potensial adalah maritim atau lebih spesifik tentang kelautan dan perikanan.

Namun Masyarakat nelayan selama ini dianggap sebagai kelompok masyarakat miskin yang termiskin (the poorer of the poorest people). Kemiskinan yang melanda kehidupan nelayan disebabkan oleh faktor-faktor yang kompleks yang tidak hanya berkaitan dengan fluktuasi musim-musim ikan, keterbatasan sumber daya manusia, modal serta akses jaringan pedagang ikan yang eksploitatif terhadap nelayan sebagai produsen, tetapi juga disebabkan oleh dampak negatif modernisasi perikanan yang mendorong terjadi pengurasan sumber daya laut secara berlebihan.

Hasil-hasil studi tentang tingkat kesejahteraan hidup dikalangan masyarakat nelayan, telah menujukkan bahwa kemiskinan dan kesenjangan sosial ekonomi atau ketimpangan pendapatan merupakan persoalan krusial yang dihadapi nelayan dan tidak mudah untuk diatasi. (Satria dalam Sugiarto, 2013).

Jawa Tengah merupakan sebuah provinsi yang berada di Pulau Jawa yang mana memiliki garis pantai sepanjang $971,52 \mathrm{~km}$ yang terbentang sepanjang pantai uatara jawa dan pantai selatan jawa. Jawa Tengah juga memiliki desa-desa pesisir yang terletakbaik di pantura dan pansela, untuk di pantura sebanyak 475 desa pesisir dan di pansela sebanyak 331 desa pesisir (DKP Jawa Tengah, 2016).

Keberadaan desa pesisir tersebut tentunya banyak masyarakat Jawa Tengah yang menggantungkan hidup dari hasil kelautan. Perbandingan produksi komoditas perikanan tangkap dan angka konsumsi ikan antar provinsi di Pulau Jawa akan di tampilkan dalam tabel dibawah ini.
Tabel 1.Produksi Perikanan Tangkap Menurut Provinsi di Pulau Jawa

\begin{tabular}{|c|c|c|c|c|}
\hline \multirow{2}{*}{ No } & \multirow{2}{*}{ Provinsi } & \multicolumn{3}{|c|}{ Tahun (Ton) } \\
\hline & & 2012 & 2013 & 2014 \\
\hline 1. & DKI Jakarta & 219.836 & 209.733 & 226.060 \\
\hline 2. & Jawa Barat & 211.711 & 218.609 & 219.004 \\
\hline 3. & Jawa Tengah & 275.559 & 243.942 & 261.017 \\
\hline 4. & $\begin{array}{l}\text { D.I. } \\
\text { Yogyakarta }\end{array}$ & 5.629 & 4.998 & 6.996 \\
\hline 5. & Jawa Timur & 381.805 & 386.895 & 399.371 \\
\hline 6. & Banten & 60.809 & 59.004 & 60.816 \\
\hline $\begin{array}{l}\text { Suml } \\
\text { Perik }\end{array}$ & $\begin{array}{lr}r: & \text { Ker } \\
\operatorname{aan} & \mathrm{RI}, \\
2015\end{array}$ & enterian & Kelaut & n dan \\
\hline
\end{tabular}

Berdasarkan tabel di atas maka dapat di jelaskan bahwa Provinsi Jawa tengah merupakan penghasil komoditas perikanan tangkap terbesar kedua setelah Provisnsi Jawa Timur. Keadaan produksi perikanan tangkap di Jawa Tengah cendrung mengalami fluktuatif berbeda halnya dengan Provinsi Jawa Timur yang benar berfokus pada peningkatan produksi perikanan tangkap, bias dilihat untuk Jawa Timur produksi perikanan setiap tahun mengalami kenaikan. Jawa Tengah sendiri jika dilihat dari potensi perikanan tangkap cukup baik jika keberadaan [otensi tersebut terus dimaksimalkan di setiap daerah kabupaten / kota. Konsumsi perikanan jika dilihat per provinsi di Pulau Jawa maka dapat di jelaskan pada tabel di bawah.

Tabel 2. Konsumsi Ikan Menurut Provsinsi di Pulau Jawa (kg/kap/tahun)

\begin{tabular}{clccc}
\multicolumn{5}{c}{ Pulau Jawa (kg/kap/tahun) } \\
\hline \multirow{2}{*}{ No } & \multicolumn{1}{c}{ Provinsi } & $\mathbf{2 0 1 2}$ & $\mathbf{2 0 1 3}$ & $\mathbf{2 0 1 4}$ \\
\hline 1. & DKI Jakarta & 31,31 & 32,95 & 32,55 \\
2. & Jawa Barat & 22,67 & 25,28 & 24,56 \\
3. & Jawa Tengah & 17,71 & 19,16 & 20,27 \\
4. & DI. Yogyakarta & 14,55 & 16,60 & 21,74 \\
5. & Jawa Timur & 23,35 & 24,46 & 27,89 \\
6. & Banten & 28,36 & 28,98 & 30,65 \\
\hline
\end{tabular}

Sumber: Kementerian Kelautan dan Perikanan RI, 2015

Tabel di atas dapat digambarkan keadaan konsumsi ikan perkapita pertahun yang ada di Pulau Jawa yang di lihat menurut provisnsi yang ada. Provinsi yang mengkonsumsi ikan yang paling tinggi yaitu DKI Jakarta yang di susul oleh Provinsi Banten. Sedangkan Provinsi Jawa Tengah merupakan provinsi yang angka 
konsumsinya tergolong paling rendah di banding provinsi-provinsi lain yang ada di Pulau Jawa. Padahal jika dilihat dari produksi perikanan tangkap Jawa Tengah merupakan penghasil komoditas terbesar kedua namun angka konsusmsi ikan masih rendah.

Sejalan dengan pelaksanaan otonomi daerah sesuai UU No. 32/2004, Kabupaten Kendal berusaha mengoptimalkan potensi daerahnya dalam berbagai sektor tidak terkecuali sektor perikanan tangkap laut. Kendal memiliki garis pantai sepanjang $41 \mathrm{~km}$, dengan memanfaatkan potensi pesisir yang ada tentunya sektor perikanan tangkap laut cukup potensial untuk terus dikembangkan (Sobari, 2007).

Melihat potensi yang ada dari perikanan tentunya membawa hal yang positif bagi peningkatan pendapatan daerah yang biasa di lihat dalam bentuk PDRB. Peningkatan PDRB merupakan hal yang positif bagi semua daerah. Oleh karena itu kontribusi setiap sektor pembangunan dalam PDRB harus terus ditingkatkan, diantaranya melalui optimalisasi pengembangan sumber daya alam yang dimiliki. Salah satu sektor yang signifikan dengan pengembangan potensi sumber daya alam adalah sektor perikanan dan kelautan (Sobari, 2007). hasil produksi perikanan tangkap dan harga jual atau nilai produksi tersebut. produksi dan nilai produksi perikanan tangkap Kabupaten Kendal dapat dilihat pada gambar di bawah.

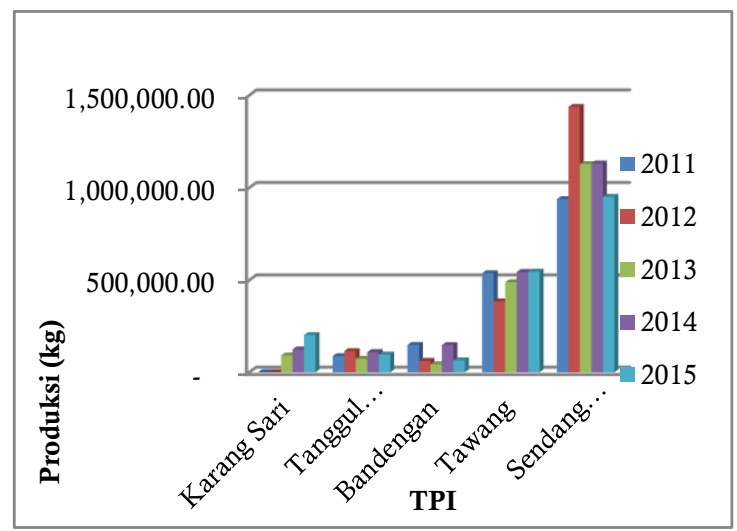

Gambar 1. Produksi Ikan Laut yang dijual di TPI Kabupaten Kendal

Sumber: Badan Pusat Statistik

Kabupaten Kendal, 2016
Menurut gambar diatas, bahwa produksi perikanan laut di Kabupaten Kendal pada tahun 2011-2015 cenderung fluktuatif. Keadaan seperti ini akan berpengaruh pada penerimaan PDRB yang ada. Kabupaten Kendal sendiri memiliki lima Tempat Pelelangan Ikan yang merupakan modal cukup potensial jika keberadaan kelima tempat pelelangan ini dimaksimalkan. Kelima TPI tersebut yaitu Karang Sari, Tanggul Malang, Bandengan, Tawang, dan Sendang Sikucing. Hasil produksi yang diperoleh oleh para nelayan yang kemudian akan dijual atau dilelang di Tempat Pelelangan Ikan. Melihat laju pertumbuhan PDRB Kabupaten Kendal berdasarkan lapangan usaha jenis pertanian, kehutanan dan perikanan maka dapat dilihat pada gambar di bawah ini.

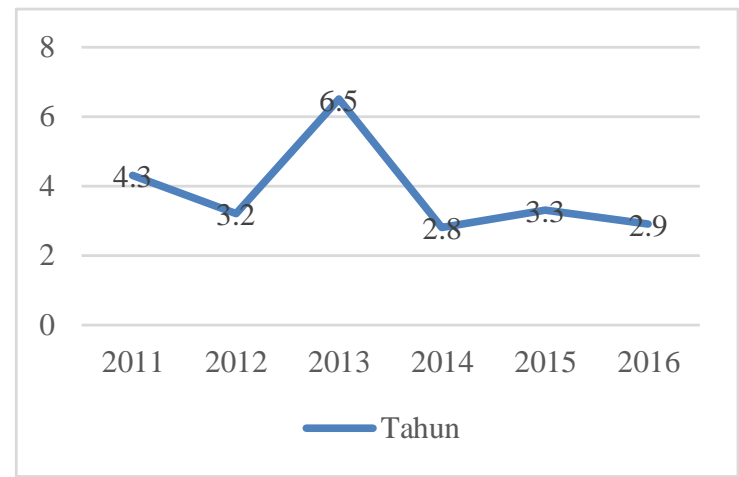

Gambar 2. Laju Pertumbuhan PDRB Jenis Lapangan Usaha Pertanian, Kehutanandan Perikanan Kab. Kendal (Persen)

Sumber: Badan Pusat Statistik Kabupaten Kendal, 2016

Gambar di atas menjelaskan bahwa kontribusi sektor pertanian yang didalamnya termasuk komoditi perikanan terhadap laju pertumbuhan PDRB Kabupaten Kendal masih tergolong fluktuatif dan bisa dikatakan mengalami penurunan jika dilihat pada beberapa tahun terakhir. Bisa dilihat pada tahun 2011 laju pertumbuhan PDRB sector pertanian sebesar 4,3\%, kemudian pada tahun 2012 mengalami penurunan sebesar $3,2 \%$. Setelah mengalami penurunan pada tahun 2012 laju pertumbuhan PDRB untuk sector pertanian mengalami kenaikan yang cukup tinggi pada tahun 2013 yaitu sebesar 6,5\%. Namun pada tahun 2014 
mengalami penurunan yang cukup drastis yaitu sebesar 2,8\%, tahun 2015 sebesar 3,3\% dan pada tahun 2016 mengalami penurunan kembali yaitu sebesar $2,9 \%$.

Berdasarkan data yang diperoleh dari BPS Kabupaten Kendal bahwa untuk jenis lapangan usaha dari sembilan sektor/17 kategori ekonomi yang ada pada PDRB tahun 2015, Kontribusi tertinggi didapat dari sektor industri pengolahan 41,15 persen, disusul sektor pertanian 21,06 persen, sektor perdagangan 12,37 persen dan konstruksi 6,55 persen. Penyumbang terbesar kedua yaitu di bidang pertanian namun di lain sisi laju pertumbuhannya cenderung mengalami penurunan. Kemudian untuk alur distribusi perikanan tangkap di Kabupaten Kendal sesuai
Perda No 10 Tahun 2010 maka hasil tangkapan para nelayan harus di lelang di TPI, berikut data perahu nelayan yang menjual hasil tangkapan melalui Tempat Pelelangan Ikan.

Berdasarkan tabel, yang merupakan data tentang keberadaan jumlah perahu motor yang kemudian hasil tangkapan perikanan laut di jual ke Tempat Pelelangan Ikan yang mana total dari seluruh perahu di Bandengan berjumlah 459 dan hanya sekitar $40 \%$ yang memalui lelang di TPI. Kemudian di Tawang terdapat 737 perahu dan ini hanya 30\% yang melakukan lelang di Tempat Pelelangan ikan. Tabel 1.5 menjelaskan bahwa untuk keberadaan TPI Sendang Sikucing, TPI Tanggul Malang, dan TPI Karang Sari mampu menyerap hampir keseluruhan hasil produksi yang diperoleh nelayan.

Tabel 3. Perahu yang masuk ke TPI tahun 2015

\begin{tabular}{lllll}
\hline No & $\begin{array}{l}\text { Tempat Pelelangan } \\
\text { Ikan }\end{array}$ & Jumlah Total Perahu & $\begin{array}{l}\text { Jumlah Perahu yang masuk } \\
\text { TPI }\end{array}$ & Persentase \\
\hline 1. & Karang Sari & 116 & 104 & $90 \%$ \\
2. & Tanggul Malang & 162 & 162 & $100 \%$ \\
3. & Bandengan & 459 & 184 & $40 \%$ \\
4. & Tawang & 737 & 221 & $30 \%$ \\
5. & Sendang Sikucing & 95 & 95 & $100 \%$ \\
\hline
\end{tabular}

Sumber : KUD Mina Jaya Kabupaten Kendal, 2016

Sehingga nilai produksi yang masuk ke Pendapatan Asli Daerah Kabupaten Kendal menjadi kurang maksimal. Karena berdasarkan Perda No 10 Tahun 2010 Pemerintah Kabupaten Kendal mendapat bagian hasil retribusi yang dipungut dari nelayan dan pedagang berdasarkankan hasil lelangan di TPI.

Pemerintah Kabupaten Kendal mendapatkan $1 \%$ dari hasil retribusi yang dilakukan di TPI yang akan masuk ke Pendapatan Asli Daerah. Kemudian sisanya sebesar $4 \%$ akan masuk ke beberapa agenda seperti biaya anggaran lelang, saving nelayan, beras paceklik, saving bakul, dana sosial, pengembangan koperasi, himpunan nelayan, serta paguyuban bakul. Keberadaan lembaga nelayan di sebuah daerah pesisir tentunya akan membawa dampak bagi nelayan itu sendiri. Bisa dilihat pada tabel 1.7 di atas bahwa nelayan yang ikut dalam organisasi atau kelembagaan nelayan akan mendapatkan pembagian dari hasil retribusi perikanan laut yang dilakukan oleh pemerintah daerah. Penentuan besaran retribusi tersebut dimaksudkan untuk saling memberikan keuntungan bagi semua pihak termasuk para nelayan yang ingin menjual hasil tangkapannya melaui TPI.

Permasalahan saat ini yang sering dihadapi oleh para nelayan yaitu tidak menentunya musim, saat musim yang kurang baik atau saat musim penghujan bnayk nelayan yang tidak melakukan kegiatan melaut karena bias membahayakan dirinya sendiri. Sehingga hasil produksi yang dilakukan nelayan menjadi kurang maksimal bahkan dalam beberapa minggu tidak dapat melaut dan tidak ada penghasilan yang masuk. Penelitian dari Nuzul Waachidah (2012) menjelaskan bahwa keadaan sosial ekonomi masyarakat pesisir Kabupaten Kendal belum terangkat kehidupan ekonominya 
Bandengan dan Desa Gempolsewu, lebih khusus di Desa Gempolsewu (Tawang) 65,80\% masyarakat masih hidup di bawah garis kemiskinan. Hal ini menunjukkan bahwa desa pesisir merupakan salah satu bagian pesisir yang sangat terbelakang, Kesulitan mengatasi masalah kemiskinan di desa-desa pesisir menjadikan wilayah peisir termasuk wilayah yang rawan di bidang sosial ekonomi. Kerawanan di bidang ini dapat menimbulkan kerawanan-kerawanan di bidang kehidupan yang lain.

Efisiensi pemasaran dapat juga di lihat dari Panjang pendeknya rantai pemasaran yang ada. Semakin Panjang rantai pemasaran perikanan maka semakin tidak efisien pemasaran yang dilakukan begitu pula sebaliknya. Pemasaran yang tidak efektif akan berdampak pada keuntungan yang diperoleh pelaku pemasaran maupun nelayan yang dalam hal ini adalah produsen akan semakin kecil karena banyak biaya yang harus dikeluarkan dalam memasarkan perikanan hingga mencapai ke tangan konsumen akhir.

Kabupaten Kendal yang memiliki potensi perikanan tangkap laut yang cukup melimpah dengan garis pantai sepanjang $41 \mathrm{~km}$. Kontribusi sektor pertanian terhadap penerimaan PDRB Kabupaten Kendal terbesar kedua setelah industri. Namun masih banyak ditemukan permasalahan yang terjadi di Kabupaten Kendal khususnya di dua wilayah pesisir yaitu Bandengan dan Tawang. Setelah melihat kontribusi hasil perikanan di daerah Bandengan dan Tawang yang sebagian besar tidak melalui mekanisme lelang di Tempat Pelelangan Ikan. Maka untuk itu diperlukan penelitian mengenai pola rantai distribusi perikanan tangkap laut yang ada di kedua wilayah tersebut dengan melihat tiga jenis komoditi perikanan yang paling dominan. Kemudian mencari besaran margin pemasaran pada setiap pelaku distribusi perikanan tangkap. Serta mencarikan model distribusi alternatif perikanan tangkap laut.

\section{METODE PENELITIAN}

Metode penelitian adalah suatu cara ilmiah untuk mendapatkan data dengan tujuan dan kegunaan tertentu. Cara ilmiah berarti kegiatan penelitian itu didasarkan pada ciri-ciri keilmuan yaitu rasional, empiris, dan sistematis. Rasional berarti kegiatan penelitian tersebut dilakukan dengan cara-cara yang masuk akal, sehingga terjangkau oleh penalaran manusia. Empiris berarti cara yang dilakukan itu dapat diamati oleh indra manusia, sehingga orang lain pun dapat mengamatinya. Sistematis berarti proses yang dilakukan dalam penelitian ini menggunakan lagkah-langkah tertentu yang bersifat logis (Amos, 2016).

Ruang lingkup dalam penelitian ini yaitu dengan melakukan analisis deskriptif dan kuantitatif. Kemudian dalam penelitian ini analisis deskriptif digunakan untuk mengetahui pola rantai distribusi perikanan tangkap di dua wilayah yaitu Bandengan dan Tawang Kabupaten Kendal, serta untuk menemukan model distribusi alternatif perikanan tangkap menggunakan pendekatan deskriptif yaitu menggambarkan keadaan yang ada di dua wilayah tersebut dengan kalimat-kalimat yang mudah dipahami dan untuk mengetahui besaran margin keuntungan dari setiap masing-masing pelaku distribusi yang ada melalui pendekatan kuantitatif.

Jenis data yang dikumpulkan meliputi data primer dan data sekunder. Data primer terdiri dari, (1) identitas responden, (2) Bentuk saluran pemasaran perikanan tangkap (lembaga yang dilalui dalam memasarkan perikanan), (3) Margin dan keuntungan yang diperoleh lembaga pemasaran (harga beli, harga jual dan jumlah perikanan yang dijual setiap lembaga pemasaran, biaya yang dikeluarkan setiap lembaga), (4) Tingkat efisiensi pemasaran pada masing-masing lembaga pemasaran (harga beli, harga jual (eceran) dan biaya yang dikeluarkan. (5) model distribusi alternatif perikanan tangkap di wilayah pesisir Bandengan dan Tawang Kabupaten Kendal.

Data sekunder merupakan data yang diperoleh dari kantor-kantor atau instansi terkait yang erat kaitannya dengan penelitian ini. Kantor-kantor yang dijadikan sumber data adalah Dinas Kelautan dan Perikan Kabupaten Kendal, Badan Pusat Statistik Kabupaten Kendal, KUD Mina Jaya yang merupakan 
koperasi yang membawahi lima TPI di Kabupaten Kendal. Adapun jenis data sekunder yang dibutuhkan adalah: keadaan umum wilayah, jumlah nelayan di wilayah Bandengan dan Tawang Kabupaten Kendal, jumlah produksi perikanan tangkap, jumlah sarana dan prasarana TPI di Kabupaten Kendal.

Populasi merupakan suatu wilayah generalisasi yang terdiri atas obyek atau subyek yang mempunyai kualitas dan karakteristik tertentu yang ditetapkan oleh peneliti untuk dipelajari dan kemudian ditarik kesimpulannya (Sugiyono, 2016). Dalam penelitian ini yang menjadi populasi adalah masyarakat nelayan yang ada di wilayah Bandengan dan Tawang Kabupaten Kendal dan kemudian pelaku pemasaran komoditas perikanan tangkap yang ada di Kabupaten Kendal, seperti pedagang pengecer, pedagang sedang, pedagang besar.

Sedangkan pengertian dari sampel adalah suatu cara pengumpulan data yang sifatnya tidak menyeluruh artinya tidak mencakup seluruh obyek penelitian akan tetapi hanya sebagian dari populasi (Supriyanto, 2003). Adapun dalam penelitian ini teknik pengambilan sampel yaitu menggunakan Purposive Sampling. Pengertian tentang purposive sampling sendiri menurut Supriyanto (2003) adalah sampling dimana pengambilan elemen-elemen yang dimasukkan dalam sampel dilakukan dengan sengaja dengan catatan bahwa sampel tersebut representative atau mewakili populasi. Selain menggunakan teknik purposive sampling penelitian ini juga memadukan dengan teknik snowball sampling yang mana obyek penelitian di rasa belum terlalu jelas sedangkan peneliti hanya mengetahui beberapa sampel saja, maka dari itu dengan menggunakan teknik snowball sampling peneliti dapat meminta salah satu ketua kelompok nelayan setempat untuk menunjukkan sampelsampel lain untuk digali informasi terkait dengan bahan penelitian yang ada

Berdasarkan jumlah populasi nelayan yang diperoleh dari Dinas Kelautan dan Perikanan Kabuapaten Kendal jumlah nelayan di daerah Desa Bandengan sebesar 540 jiwa, dan di Desa Gempolsewu (Tawang) berjumlah 836 jiwa dengan total populasi kedua wilayah tersebut adalah 1376. Kemudian untuk populasi pedagang perikanan di wilayah Bandengan dan Tawang sebagai berikut. Untuk pedagang besar di Bandengan berjumlah 5 orang dan di Tawang berjumlah 5 orang dengan total 10 orang, Pedagang sedang di Bandengan 30 orang dan di Tawang 23 orang dengan jumlah total 53 orang. Kemudian untuk pedagang kecil atau pengecer di Bandengan 46 orang dan di Tawang 54 dengan jumlah total 100 orang. Penelitian ini juga dalam pengambilan sampel dipadukan dengan snowball sampling atau teknik penentuan sampel yang mula-mula jumlahnya kecil kemudian membesar, ibarat bola salju yang menggelinding yang lama-lama menjadi besar, karena jumlah dan keberadaan sampel tidak terlalu jelas (Sugiyono, 2016).

Teknik pengumpulan data yaitu dengan cara interview (wawancara) digunakan sebagai teknik pengumpulan data apabila peneliti ingin melakukan studi pendahuluan untuk menemukan permasalahan yang harus diteliti. Juga apabila peneliti ingin mengetahui hal-hal yang mendalam dan jumlah respondennya sedikit. Kuesioner (Angket) merupakan teknik pengumpulan data yang dilakukan dengan cara memberi seperangkat pertanyaan atau pernyataan tertulis kepada responden untuk dijawabnya. Observasi sebagai teknik pengumpulan data mempunyai ciri yang spesifik bila dibandingkan dengan teknik yang lain, observasi tidak terbatas pada orang melainkan juga pada obyek-obyek alam yang lain (Sugiyono, 2016). Studi Pustaka merupakan teknik pengambilan data yang bersumber dari buku, jurnal, mapun literature lainnya yang memenuhi kaidah keilmiahan.

Teknik analisis data dalam penelitian ini yaitu analisis deskriptif. Analisis deskriptif yaitu sebuah analisis yang menggambarkan suatu keadaan secara jelas berdasarkan keadaan real di lapangan. Analisis deskriptif ini digunakan untuk menggambarkan pola rantai distribusi perikanan tangkap laut yang ada di Bandengan dan Tawang Kabupaten Kendal. Menurut Arikunto (2010) dalam penelitian deskriptif apabila datanya telah terkumpul, maka diklasifikasikan menjadi dua kelompok data, yaitu kuantitatif yang berbentuk 
angka-angka dan kualitatif yang dinyatakan dalam kata-kata atau simbol. Data kualitatif disisihkan untuk sementara, karena sangat berguna untuk menyertai dan melengkapi gambaran yang diperoleh dari analisis data kuantitatif. Kemudian untuk mudah dipahami maka dapat dicari dengan proporsi (persentase) berdasarkan data penelitian yang ada yang kemudian akan diklasifikasikan agar mendapatkan kesimpulan dari data tersebut. Pengolahan data persentase diperoleh dengan rumus sebagai berikut:

$\mathrm{F}=\frac{f}{n} \times 100 \%$

Keterangan :

$\mathrm{F}=$ frekuensi relatif/angka persentase

$\mathrm{F}=$ frekuensi yang sedang dicari persentasenya

$\mathrm{n}=$ jumlah seluruh data

$100 \%=$ Konstanta

(Ali, 1987 dalam Bagas, 2013)

Menurut Masyrofie (1994) dalam Ningsih (2011) untuk mengetahui margin pemasaran, distribusi, share (bagian), seluruh keuntungan lembaga-lembaga pemasaran yang terlibat terhadap margin total dari berbagai saluran pemasaran maka digunakan analisis margin pemasaran. Besarnya margin pemasaran dapat dihitung dengan rumus:

$\mathrm{MP}=P_{r}-P_{f}$

Untuk satu level pedagang margin pemasaran dihitung dengan rumus:

$\mathrm{MP}=\mathrm{KP}+\mathrm{BP}$

Keterangan :

$\mathrm{MP}=$ Margin pemasaran

$\operatorname{Pr}=$ Harga di tingkat konsumen yang diambil dari harga beli rata-rata

Pf $=$ Harga ditingkat produsen yang diambil dari harga jual rata-rata

$\mathrm{BP}=$ Biaya pemasaran

$\mathrm{KP}=$ Keuntungan Pemasaran $(\mathrm{MP}-\mathrm{BP})$

Untuk menghitung share (bagian) harga yang diterima nelayan dihitung dengan rumus:

$S f=\frac{P_{f}}{P_{r}} x 100$
Keterangan:

$S_{f}=$ Share (bagian) harga yang diterima nelayan

$P_{f}=$ Harga ditingkat nelayan

$P_{r}=$ Harga di tingkat pedagang (bakul)

Indikator efisien pemasaran dapat diukur dengan kriteria bahwa jika share yang diterima nelayan lebih besar dari share margin pemasarannya maka saluran pemasaran tersebut dikatagorikan efisien. Jika share harga yang diterima nelayan lebih kecil dari share marjin pemasarannya, maka saluran pemasaran tersebut dikatagorikan tidak efisien.

Sebuah penelitian perlu adanya sebuah pemecahan masalah dari permasalahan yang ada yaitu dengan cara menggunakan sebuah alat analisis, penelitian kali ini alat analisis yang digunakan yaitu flowchart (bagan alir) merupakan representasi secara grafik dari satu algoritma atau prosedur untuk menyelesaikan suatu masalah (Lasminiasih dkk, 2016). Penggunaan flowchart dalam penelitian ini yaitu bertujuan untuk mempermudah memahami masalah yang ada serta menemukan alternatif pemecahan masalah yang ada. Menurut Opik Taupik, Mohamad Irfan, dan Ai Nurpianti dalam jurnalnya tahun 2013 menyatakan bahwa sistem flowchart digunakan untuk menunjukkan alur kerja atau apa yang sedang dikerjakan didalam sistem secara keseluruhan dan menjelaskan urutan prosedur-prosedur yang ada dalam sistem.

\section{HASIL DAN PEMBAHASAN}

Sistem pemasaran yang terjadi pada komoditas perikanan memang sebagian bisar tidak langsung masuk ketangan konsumen melainkan harus melalui beberapa saluran tata niaga yang ada. Sama halnya dengan komoditas pertanian lain yang mana perlu ada perlakuan khusus dalam memasarkan hasil perikanan. Berbeda dengan produk non pertanian yang mana saluran distribusnya tidak terlalu panjang. Perlakuan pasca penen diperlukan untuk menjaga kualitas komoditas perikanan, maka diperlukan lembaga-lembaga pemasaran yang mana lembaga tersebut melakukan fungsi pemasaran pada masing-masing tingkatan. 
Pola rantai distribusi perikanan tangkap di Kabupaten Kendal memiliki beberapa pola yaitu seperti hasil perhitungan persentase yang sudah dilakukan di atas maka saluran tata niaga yang pertama yaitu nelayan ke pedagang sedang ke pedagang besar ke pabrik atau pasar ikan ke konsumen akhir. Kedua nelayan ke pedagang sedang ke pedagang pengecer ke konsumen. Ketiga nelayan ke pedagang sedang ke konsumen. Ketiga pola tersebut merupakan pola rantai distribusi yang paling dominan yang ada di dua wilayah baik itu di Bandengan dan Tawang.Kemudian untuk memahami lebih jelas mengenai pola saluran distribusi perikanan tangkap laut di Bandengan dan Tawang Kabupaten Kendal maka dapat dilihat pada gambar dibawah ini :

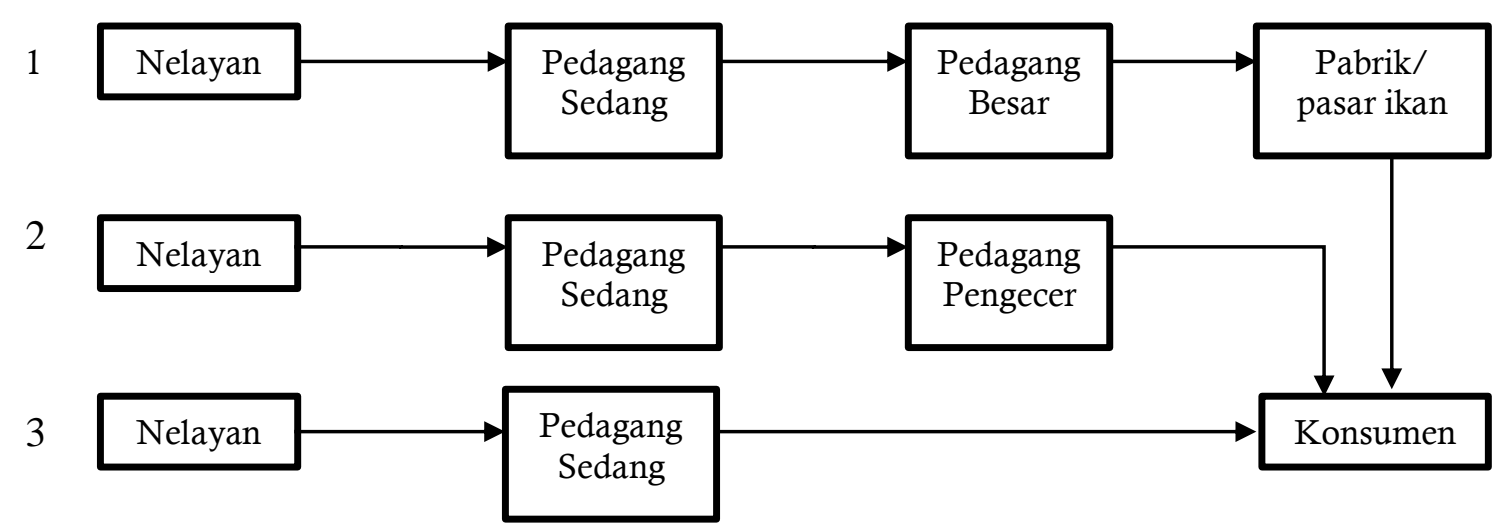

Keterangan

Rantai Distribusi Perikanan

Gambar 3. Pola Rantai Distribusi Perikanan Tangkap di Bandengan dan Tawang Kabupaten Kendal

Sumber: Data Primer, 2017

Gambar di atas merupakan keadaan pola rantai distribusi perikanan tangkap laut yang ada di Bandengan dan Tawang Kabupaten Kendal dimana terdapat tiga pilihan alur distribusi. Sebagian besar nelayan menjual hasil tangkapannya kepada pedagang sedang yaitu sebesar 79\%. Sistem penjualan komoditi perikanan tangkap di Bandengan dan Tawang mayoritas tidak melalui system lelang yang dilakukan oleh TPI. Sehingga ikan akan masuk ke pedagang dalam hal ini adalah pedagang sedang yang sering membantu nelayan dalam segi permodalan. Kondisi pemasaran ikan dari nelayan langsung kepada konsumen akan terasa sulit karena nelayan membutuhkan modal kembali untuk melaut di keesokan harinya dan selain itu tidak ada waktu senggang nelayan dalam menjual langsung tangkapannya. Selain itu nelayan juga membutuhkan istirahat, mempersiapkan peralatan yang akan digunakan kembali guna untuk menjaga kuantitas hasil tangkapan. Sesuai dengan konsep yang diungkap oleh Charles, Joseph, dan McDaniel dalam bukunya yang berjudul pemasaran tahun 2001 yang menyatakan bahwa organisasi-organisasi atau pelaku yang melakukan distribusi perikanan tangkap laut di Kabupaten Kendal saling tergantung dari produsen yang memiliki ketergantungan dengan pedagang sedang. Ketergantungan bisa dilihat dari banyaknya nelayan yang menjual hasil tangkapannya langsung ke pedagang sedang tanpa melalui proses lelang di TPI setempat. Selain mempunya sangkutan hutang nelayan juga memilih menjual langsung dengan tujuan bisa langsung memasarkan hasil tangkapannya dan mendapatkan modal kembali untuk melaut serta untuk mencukupi kebutuhan sehari-hari.

Pedagang besar juga tergantung ke pedagang sedang dimana pedagang besar lebih 
mudah membeli perikanan ke pedagang sedang yang sudah menjadi langganan. Sesuai dengan yang dinyatakan oleh Wawan Oktariza dkk pada jurnalnya bahwa dalam pendistribusian produk perikanan pasti diperlukan adanya saluran pemasaran. Pelaku atau organisasi yang saling tergantung yang menjangkau dari titik awal suatu produk hingga sampai ke tangan pelanggan atau konsumen dengan tujuan memindahkan tujuan produk ke tujuan konsumsi akhir.

Produsen harus mempertimbangkan berbagai macam faktor yang sangat berpengaruh dalam pemilihan saluran distribusinya. Pemilihan saluran distribusi yang efektif akan mampu mendorong peningkatan penjualan yang diharapkan, sehingga kelangsungan hidup produsen dapat terjamin (Nurbaity, 2004). Setiap saluran distribusi memiliki permasalahan masing-masing. Permasalahan yang sering ditemui oleh nelayan yaitu harga komoditas ikan yang rendah karena harga ditentukan oleh pedagang sehingga nelayan tidak bisa melakukan tawar menawar. Kurangnya informasi mengenai perkembangan harga komoditas perikanan laut sehingga nelayan tidak mengetahui kepada siapa hasil tangkapan tersebut akan dijual pada tingkatan yang lebih menguntungkan. Selain faktor luar ada juga faktor dari dalam diri nelayan itu sendiri yaitu seperti hanya berpendidikan rendah sehingga kemampuan nelayan untu memahami sumber informasi yang ada sangatlah kurang

Tentunya jika dalam saluran distribusi perikanan tangkap laut melewati pelaku tata niaga maka itu akan mengakibatkan besarnya biaya distribusi atau margin yang terlalu tinggi. Besarnya biaya pemasaran karena ada bagian yang harus dikeluarkan sehingga akan mengurangi keuntungan dari pelaku tata niaga yang ada. Kondisi seperti ini justru akan memperkecil bagian yang harus diterima oleh nelayan dan akan memperbesar biaya yang harus dikeluarkan oleh konsumen. Hal ini sesuai dengan yang diungkapkan oleh Kustiawati Ningsih pada jurnalnya bahwa semakin pendek rantai distribusi maka share harga yang diterima nelayan akan semakin besar. Namun jika semakin panjang rantai distribusi maka share harga yang diterima nelayan akan semakin kecil dan justru semakin besar yang diterima konsumen akhir.

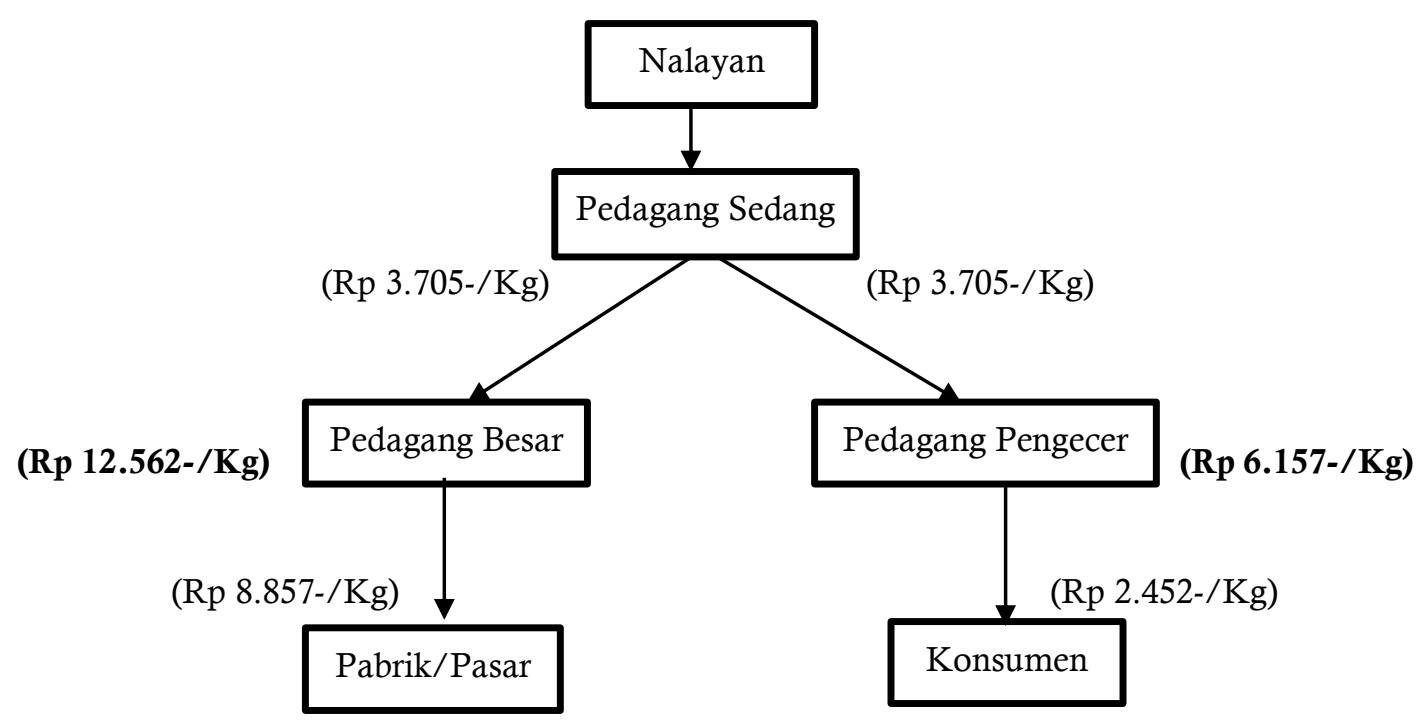

Gambar 4. Pola Distribusi dan Margin Pemasaran Jenis Komoditi Cumi-cumi Sumber: Data Primer, 2017

Sesuai gambar tersebut mengenai pola rantai distribusi komoditas perikanan tangkap laut, maka akan dijelaskan gambaran pola rantai distribusi tersebut dengan keadaan marjin pemasaran yang ada pada tiga jenis komoditi perikanan yang paling dominan. Berikut mengenai skema margin pemasaran komoditas Cumi-cumi yang ada di Bandengan dan Tawang 
Kabupaten Kendal yang dapat dilihat pada gmbar Sesuai dengan pengertian dari margin pemasaran yang merupakan selisih harga yang diterima produsen dengan harga yang dibayarkan oleh konsumen, untuk komoditas Cumi-cumi dan jenis komoditas ikan laut memiliki margin pemasaran yang berbeda-beda karena seuai dengan harga turunan yang dilakukan oleh mekanisme pasar. Gambar diatas merupakan skema pola rantai distribusi perikanan tangkap laut jenis komoditi cumi-cumi. Berdasarkan gambar diatas maka dapat diketahui bagaimana pola distribusi yang ada di Bandengan dan Tawang Kabupaten Kendal.

Penerimaan margin pemasaran untuk pedagang sedang yaitu $\mathrm{Rp} 3.705-/ \mathrm{Kg}$ atau $8,6 \%$ dari perbandingan farmer share yang paling tinggi. Kemudian untuk keuntungan bersih dari pedagang sedang yaitu sebesar $\mathrm{Rp} 3.015-/ \mathrm{Kg}$ ikan segar, hasil keuntungan bersih tersebut setelah dikurangi oleh biaya-biaya pemasaran yang sebesar Rp 690-/Kg. Biaya pemasaran yang dikeluarkan meliputi biaya transportasi, biaya bongkar muat, biaya retribusi dan biaya pengawetan. Untuk pedagang besar memiliki margin pemasaran sebesar $\mathrm{Rp} 8.857-/ \mathrm{Kg}$ atau sekitar $21 \%$ dengan keuntungan bersih yaitu sebesar Rp 5.821-/Kg yang telah dikurangi biaya pemasaran, biaya pemasaran untuk pedagang besar yaitu sebesar $\mathrm{Rp} \mathrm{3.036-/Kg} \mathrm{ikan} \mathrm{segar.}$ Besarnya biaya pemasaran untuk pedagang besar karena volume pembelian untuk pedagang besar tergolong tinggi sehingga membutuhkan biaya transportasi yang lebih besar, biaya bongkar muat dan biaya pengawetan yang besar pula. Sedangkan untuk pedagang pengecer memiliki margin pemasaran sebesar Rp2.452-/Kg dimana terdapat biaya pemasaran yang harus dikeluarkan untuk pedagang pengecer yaitu sebesar Rp 444-/Kg. Kemudian untuk keuntungan bersih dari pedagang pengecer yaitu sebesar $\mathrm{Rp}$ 2.008-/Kg ikan segar. Margin pemasaran untuk jenis komoditi lain seperti Udang akan dijelaskan pada gambar di bawah ini:

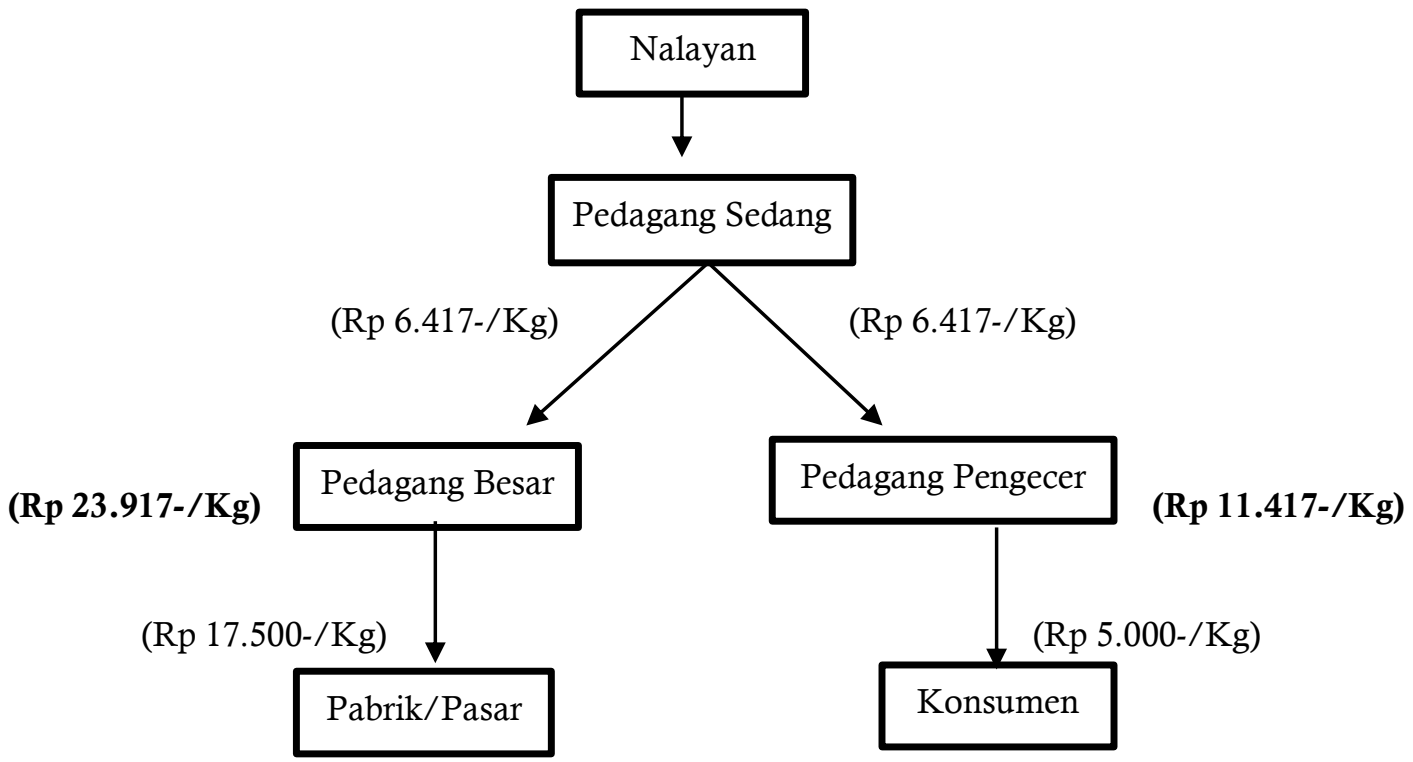

Gambar 6. Pola Distribusi dan Margin Pemasaran Jenis Komoditi Udang

Sumber: Data Primer, 2017

Gambar diatas merupakan skema pola rantai distribusi perikanan tangkap laut jenis komoditi udang. Berdasarkan gambar diatas maka dapat diketahui bagaimana pola distribusi yang ada di Bandengan dan Tawang Kabupaten Kendal. Selisih harga dari tangan nelayan hingga ke konsumen akhir atau pabrik pengolah ikan terdapat perbedaan selisih harga yaitu untuk saluran distribusi yang melalui pedagang pengecer memiliki selisih harga $\mathrm{Rp} 11.417-/ \mathrm{Kg}$, harga tersebut lebih sedikit di banding jika melalui saluran distribusi dengan pedagang besar 
yang mana selisih harga hingga $\mathrm{Rp} 23.917-/ \mathrm{Kg}$. Berbedaan selisih harga tersebut dikarenakan adanya berbedaan biaya pemasaran antara pedagang besar dengan pedagang pengecer.

Penerimaan margin pemasaran untuk pedagang sedang yaitu $\mathrm{Rp} 6.417-/ \mathrm{Kg}$ atau $5 \%$ dari perbandingan farmer share yang paling tinggi. Kemudian untuk keuntungan bersih dari pedagang sedang yaitu sebesar $\mathrm{Rp} 5.973-/ \mathrm{Kg}$ ikan segar, hasil keuntungan bersih tersebut setelah dikurangi oleh biaya-biaya pemasaran yaitu sebesar Rp 690-/Kg. Biaya pemasaran yang dikeluarkan meliputi biaya transportasi, biaya bongkar muat, biaya retribusi dan biaya pengawetan. Untuk pedagang besar memiliki margin pemasaran sebesar $\mathrm{Rp} 17.500-/ \mathrm{Kg}$ atau sekitar 13,7\% dengan keuntungan bersih yaitu sebesar Rp 14.464-/Kg yang telah dikurangi biaya pemasaran, biaya pemasaran untuk pedagang besar yaitu sebesar Rp 3.036-/Kg ikan segar. Sedangkan untuk pedagang pengecer memiliki margin pemasaran sebesar Rp5.000/Kg dimana terdapat biaya pemasaran yang harus dikeluarkan untuk pedagang pengecer yaitu sebesar $\mathrm{Rp}$ 444-/Kg. Kemudian untuk keuntungan bersih dari pedagang pengecer yaitu sebesar Rp 4.310-/Kg ikan segar. Margin pemasaran untuk jenis komoditi lain seperti ikan Kembung akan dijelaskan pada gambar di bawah ini :

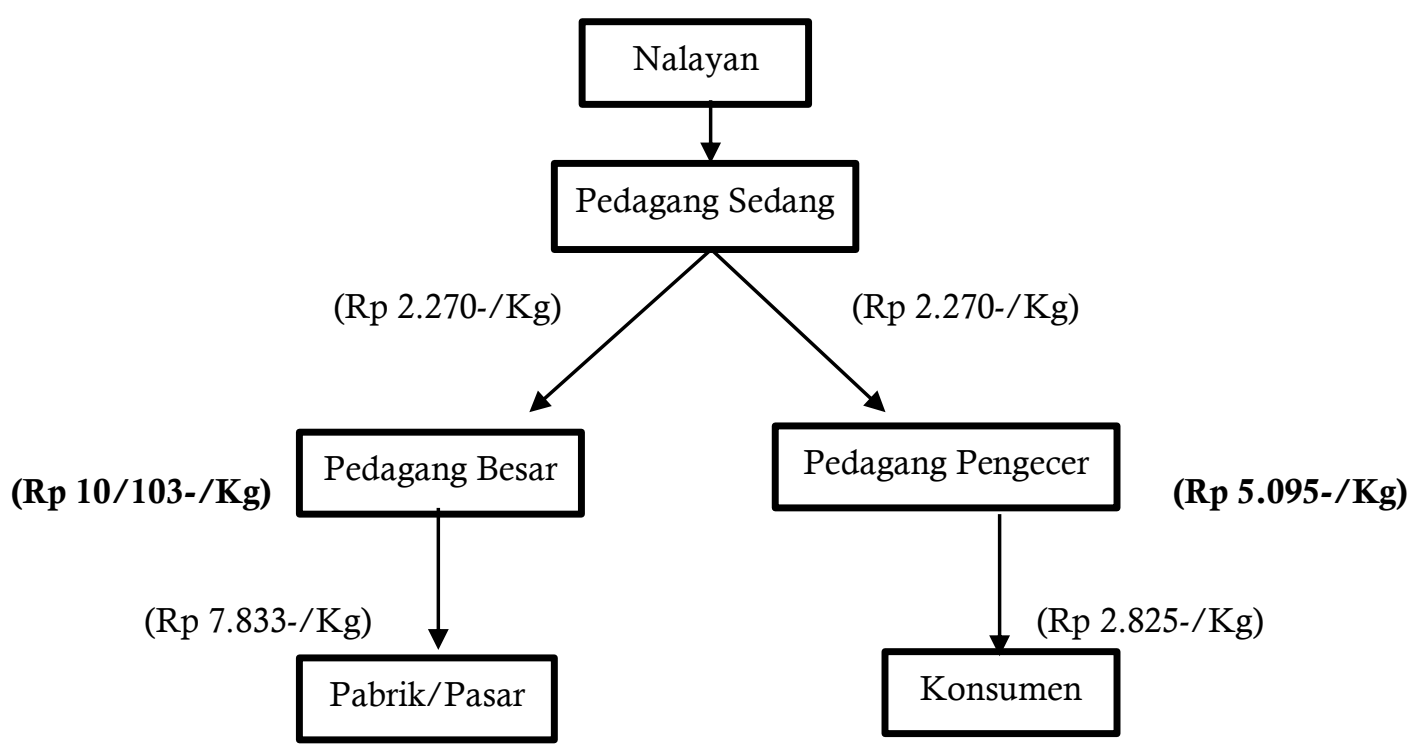

Gambar 7. Pola Distribusi dan Margin Pemasaran Jenis Komoditi Ikan Kembung Sumber: Data Primer, 2017

Gambar 4.5 merupakan skema pola rantai distribusi perikanan tangkap laut jenis komoditi ikan kembung. Berdasarkan gambar diatas maka dapat diketahui bagaimana pola distribusi yang ada di Bandengan dan Tawang Kabupaten Kendal. Selisih harga dari tangan nelayan hingga ke konsumen akhir atau pabrik pengolah ikan terdapat perbedaan selisih harga yaitu untuk saluran distribusi yang melalui pedagang pengecer memiliki selisih harga Rp 5.095-/Kg, harga tersebut lebih sedikit dibanding jika melalui saluran distribusi dengan pedagang besar yang mana selisih harga hingga Rp 10.103-/Kg. Berbedaan selisih harga tersebut dikarenakan adanya berbedaan biaya pemasaran antara pedagang besar dengan pedagang pengecer.

Penerimaan margin pemasaran untuk pedagang sedang yaitu $\mathrm{Rp} 2.270-/ \mathrm{Kg}$ atau 9\% dari perbandingan farmer share yang paling tinggi. Kemudian untuk keuntungan bersih dari pedagang sedang yaitu sebesar $\mathrm{Rp} 1.580-/ \mathrm{Kg}$ ikan segar, hasil keuntungan bersih tersebut setelah dikurangi oleh biaya-biaya pemasaran yaitu sebesar Rp 690-/Kg. Biaya pemasaran yang 
dikeluarkan meliputi biaya transportasi, biaya bongkar muat, biaya retribusi dan biaya pengawetan. Untuk pedagang besar memiliki margin pemasaran sebesar Rp 7.833-/Kg dengan keuntungan bersih yaitu sebesar $\mathrm{Rp} 4.979-/ \mathrm{Kg}$ yang telah dikurangi biaya pemasaran, biaya pemasaran untuk pedagang besar yaitu sebesar Rp 3.036-/Kg ikan segar. Sedangkan untuk pedagang pengecer memiliki margin pemasaran sebesar $\mathrm{Rp} 2.825-/ \mathrm{Kg}$ dimana terdapat biaya pemasaran yang harus dikeluarkan untuk pedagang pengecer yaitu sebesar $\mathrm{Rp} 444-/ \mathrm{Kg}$. Kemudian untuk keuntungan bersih dari pedagang pengecer yaitu sebesar $\mathrm{Rp} 2.381-/ \mathrm{Kg}$ ikan segar.

Secara keseluruhan setelah melihat perhitungan margin yang ada pada setiap komoditi di atas maka dapat disimpulkan bahwa yang menikmati keuntungan bersih paling tinggi yaitu pedagang besar. Karena pedagang besar dalam hal ini yang mampu membeli volume ikan yang peling tinggi yang mereka akan dijual ke pabrik pengolah ikan sehingga untuk menutupi biaya pemasaran yang tinggi maka harga jual pun semakin tinggi. Penyaluran atau pendistribusian hasil perikanan selalu membutuhkan lembaga-lembaga lain karena tidak bisa nelayan langsung menjual hasil tangkapannya ke konsumen. Panjangnya saluran distribusi tersebut tentunya mengakibatkan nilai tambah dari setiap kegiatan di pelaku tata niaga yang ada. Nelayan tidak bisa menikmati nilai tambah dari yang dihasilkan oleh para pedagang.

Semakin tinggi nilai tambah dari komoditas perikanan maka tidak akan dinikmati oleh nelayan maupun konsumen melainkan akan dinikmati oleh para pedagang baik itu sedang, besar dan kecil. Sama halnya jika harga di tingkat produsen berbeda pada harga yang dibeli pada tingkat konsumen karena adanya selisih dari margin pemasaran yang terjadi maka respon dari konsumen akan permintaan perikanan tergantung pada besarnya margin pemasaran yang ada. Pemasaran dapat dinyatakan efisien bila mampu mengandalkan pembagian keuntungan yang adil kepada semua pihak yang ikut dalam kegiatan pemasaran dari keseluruhan harga yang dibayarkan konsumen akhir. Hal ini sesuai yang dinyatakan oleh Arman Hassain dalam jurnanya bahwa semakin pendek saluran distribusi akan lebih menguntungkan untuk produsen dan konsumen akhir.

Analisis mengenai permasalahan yang ada atau kendala yang dialami oleh nelayan akan dijelaskan dalam bentuk diagram alir (Flowchart).

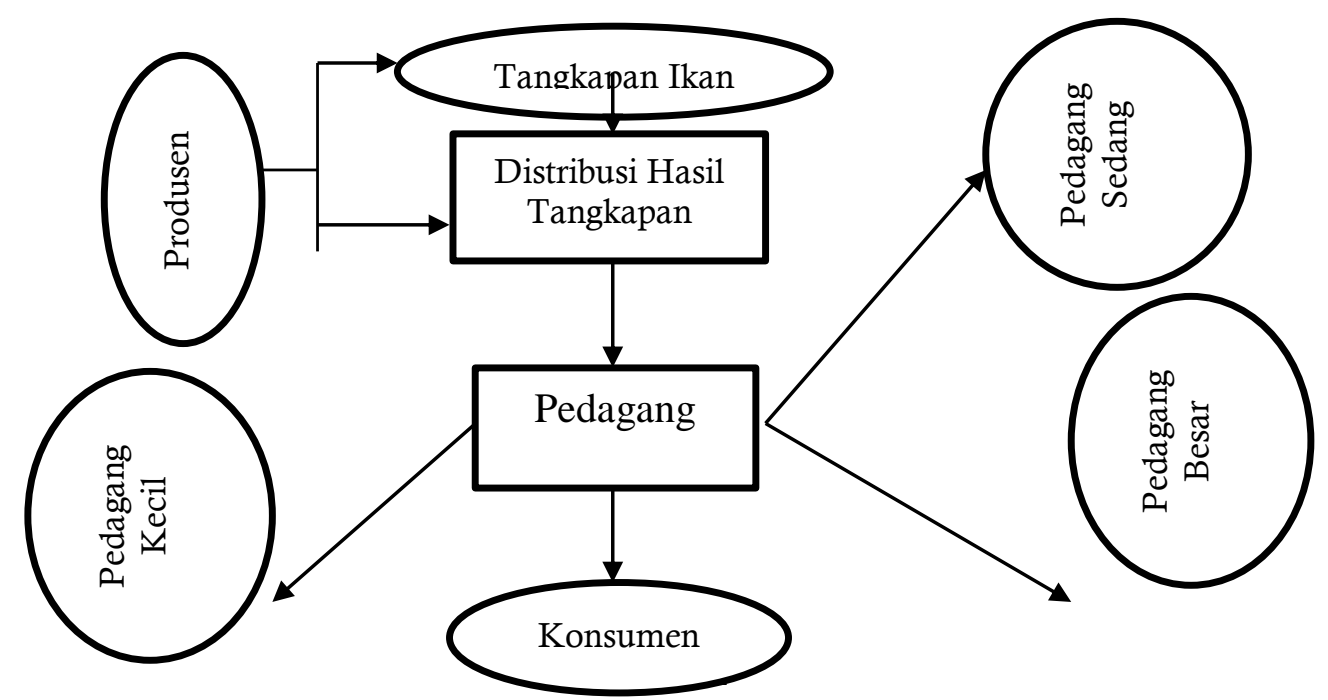

Gambar 8. Diagram Alir Distribusi Perikanan Tangkap Laut di Bandengan dan Tawang Kabupaten Kendal 
Flowchart digunakan untuk memudahkan pembaca dalam melihat keadaan yang sebenarnya terjadi dilingkungan nelayan. Kendala dalam memasarkan hasil tangkapan akan berpengaruh terhadap harga jual yang ada di produsen (nelayan) sehingga hasil yang didapatkan tidak akan maksimal. Terbentuknya diagram alir diharapkan akan menemukan pola distribusi perikanan tangkap alternatif di luar pola distribusi yang sudah ada dengan harapan pula pola distribusi yang baru akan meningkatkan pendapatan nelayan karena harga jual dari nelayan bisa cukup tinggi. Berikut gambaran mengenai kendala-kendala yang dihadapi oleh nelayan dalam memasarkan hasil perikanannya dan solusi yang bisa dijadikan masukan dalam kegiatan distribusi perikananBerdasarkan gambar di atas maka dapat dijelaskan bahwa kegiatan proses distribusi perikanan dimulai dari produsen menangkap hasil perikanan di laut yang kemudian hasil tangkapan tersebut akan dijual langsung ke pedagang ikan sebelum masuk ke tangan konsumen. Pedagang yang terlibat dalam distribusi perikanan tangkap yaitu pedagang sedang, pedagang besar, dan pedagang kecil yang mana dari masing-masing pedagang tersebut mempunya fungsi dan tugas yang berbeda-beda. Proses distribusi berdasarkan diagram alir (flowchart) di atas masih menggunakan distribusi langsung atau yang bisa disebut produsen menjual hasil tangkapannya langsung ke pedagang tanpa melalui mekanisme penjualan yang semestinya. Proses distribusi diatas berdasarkan hasil penelitian masih banyak ditemukan permasalahan atau kendala yang dihadapi oleh para produsen (nelayan) dalam memasarkan hasil tangkapannya.

Kendala-kendala yang dihadapi oleh produsen (nelayan) dalam pendistribusian perikanan semuanya akibat dari kurangnya modal oleh para nelayan itu sendiri. Karena kurangnya modal tersebut nelayan harus meminjam modal kepada bakulan sehingga hasil tangkapan nelayan harus dijual kepada bakulan tersebut yang memberikan modal dan harga beli dari bakulan bisa dikatakan di bawah harga pasaran ikan. Nelayan sesungguhnya mempunyai berbagai alternatif untuk memilih saluran distribusi yang menguntukngkan bagi dirinya atas dasar tingkat harga yang ditawarkan oleh pedagang pengumpul (Johanson, 2013).

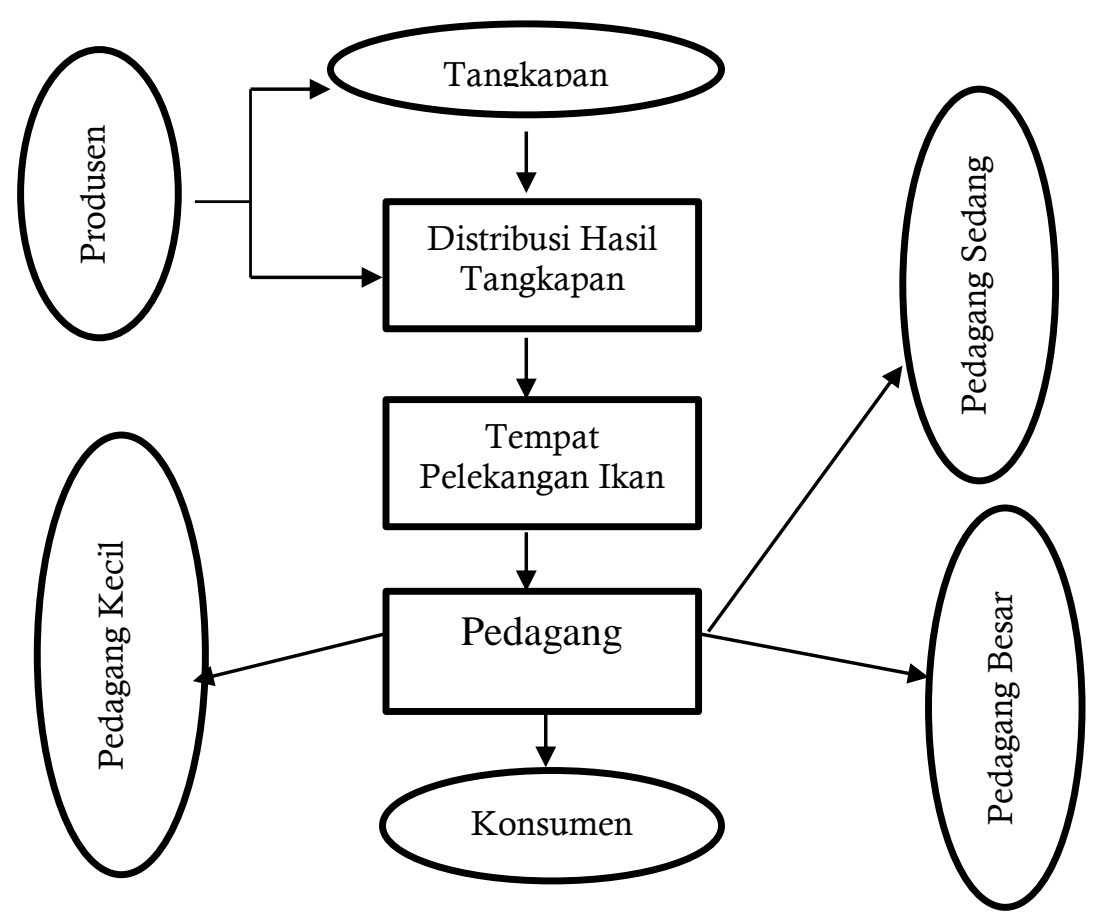

Gambar 9. Diagram Alir Distribusi Alternatif Perikanan Tangkap Laut di Bandengan dan Tawang Kabupaten Kendal 
Melihat kendala-kendala di atas atau permasalahn yang dialami oleh para nelayan maka muncul beberapa solusi untuk memberikan masukan yaitu dengan memberika permodalan yang cukup untuk para nelayan sehingga mereka bisa melaut tanpa harus membuat pinjaman ke bakulan. Peminjaman modal yang dilakukan pemerintah daerah yaitu dengan cara pemberdayaan koperasi yang sudah ada khusus untuk kelompok nelayan yang sudah terdaftar resmi di catatan pemerintah daerah. Pemberdayaan koperasi dengan tujuan nelayan yang kekurangan modal bisa meminjam melalui koperasi dengan begitu para nelayan tidak memiliki sangkutan dengan para bakulan sehingga hasil tangkapan bisa dijual melalui mekanisme lelang yang ada yaitu lewat Tempat Pelelangan Ikan.

Sistem penjualan komoditas perikanan jika melalui sistem lelang maka akan membawa manfaat pada pendapatan daerah karena disitu pemerintah daerah bisa memungut retribusi sebesar $1 \%$ dari hasil lelangan yang dilakukan. Melihat kendala atau permasalahan yang terjadi pada distribusi perikanan tangkap laut yang dihadapi oleh para nelayan dan solusi yang ditawarkan maka diagram alir (Flowchart) yang semestinya untuk dijadikan model distribusi alternatif yaitu sebagai berikut:

Berdasarkan gambar 4.7 di atas maka fungsi Tempat Pelelangan Ikan harus diutamakan kembali sebagai tempat pendistribusian komoditas perikanan tangkap laut baik itu di wilayah Bandengan maupun wilayah Tawang yang keduanya berada di wilayah Kabupaten Kendal. Sudah di ketahui permasalahan yang ada yaitu masih rendahnya penyerapan oleh Tempat Pelelangan Ikan di dua wilayah tersebut sehingga mengakibatkan rendahnya pula hasil retribusi yang diterima oleh pemerintah daerah Kabupaten Kendal. Berfungsinya Tempat Pelelangan Ikan kembali akan membawa dampak baik itu dari nelayan maupun ke pemda, untuk nelayan harga jual akan lebih baik dibanding jika langsung menjual ke bakulan karena dengan mekanisme lelang nelayan bisa melakukan tawar menawar harga sehingga harga sesuai dengan yang diinginkan.
Sesuai yang dinyatakan oleh Carmen dkk pada jurnalnya yaitu bahwa pemilihan spesifikasi yang berkualitas di semua tahap pemasaran akan mendorong peningkatan dalam memenuhi kebutuhan konsumen, pengurangan biaya yang dikeluarkan, dan peningkatan penjualan yang esensial. Pemilihan spesifikasi yang berkualitas atau pemilihan distribusi yang menguntungkan akan membawa nelayan pada taraf hidup yang lebih baik.

\section{SIMPULAN}

Kesimpulan dalam penelitian ini yaitu Terdapat tiga pola distribusi perikanan, dan terdapat beberapa kendala dalam memasarkan karena kurangnya modal dari nelayan. Saran yang diberikan yaitu pengembangan akses permodalan nelayan, informasi harga komoditas yang jelas bisa dilakukan oleh Tempat Pelelangan Ikan, dan Penguatan Kelembagaan nelayan dan masyarakat pesisir

\section{DAFTAR PUSTAKA}

Amos, Neolaka. (2016). Metode Penelitian dan Statistik. Bandung: Remaja Rosdakarya.

Arikunto, S. (2010). Prosedur Penelitian: Suatu Pendekatan Praktik. (Edisi Revisi). Jakarta: Rineka Cipta.

Badan Pusat Statistik Kabupaten Kendal. (2016). Kendal Dalam Angka 2016. Kendal: BPS.

Bagas Pamangkus, Septian. (2013). Analisis Rantai Distribusi Komoditas Ikan Tangkap Perikanan Laut di Kota Tegal. Skripsi. Semarang: Universitas Negeri Semarang.

Dinas Kelautan dan Perikanan Provinsi Jawa Tengah Tahun 2016

Kementrian Kelautan dan Perikanan. (2015). Angka Konsumsi Ikan 2010-2015. Jakarta: KKP.

KUD Mina Jaya Kabupaten Kendal. (2016). Data Besaran Retribusi Perikanan. Kendal.

Lasminiasih, Dkk. (2016). Perancangan Sistem Informasi Kredit Mikro Mahasiswa Berbasis WEB. Jurnal. Jakarta: Universitas Gunadarma.

Ningsih, Kustiawati. (2011). Analisis Saluran dan Margin Pemasaran Petani Jambu Air Camplong (syzygium aqueum). Jurnal. Madura: Universitas Islam Madura.

Nurbaity Lubis, Arlina. (2004). Peranan Saluran Distribusi dalam Pemasaran Produk dan Jasa. 
Assafrul Ali Adhim \& Etty Soesilowati/ Economics Development Analysis Journal 7 (4) (2018)

Karya Ilmiah. Medan: Universitas Sumatera Utara.

Oktariza, Wawan dkk. (1996). Studi Distribusi Pemasaran Hasil Perikanan Laut dari Pelabuhan Ratu, Sukabumi, Jawa Barat. Buletin Ekonomi Perikanan. ISSN 0854-5804. Bogor. Institut Pertanian Bogor.

Perda No 10 Tahun 2010 Pasal 4, 15, 19 Tentang Pengelolaan dan Retribusi Tempat Pelalangan Ikan. Kabupaten Kendal.

Republik Indonesia. 2004. Undang-Undang No 32 Tahun 2004 Tentang Pemerintahan Daerah. Jakarta.

Sobari, M. Prihatna dan Arifatul, Nova. (2007). Peranan Sektor Perikanan dan Kelautan Terhadap Pembangunan Wilayah Kabupaten Kendal, Provinsi jawa Tengah. Bulletin Ekonomi
Perikanan Vol. VII. No. 1 Tahun 2007. Kendal.

Sugiyono. (2016). Metode Penelitian Pendidikan: Pendekatan Kuantitatif, Kualitatif, dan R\&D. Bandung: Cv. Alfabeta.

Supriyanto J., (2003), Metode Riset dan Aplikasinya Dalam Pemasaran, Edisi Ketujuh. Jakarta: Rineka Cipta.

Taupik, Opik. Irfan, Muhammad. Nurpainti, Ai. (2013). Pembuatan Aplikasi Anbiyapedia Ensiklopedi Muslim Anak Berbasis WEB. Jurnal. Bandung: UIN Sunan Gunung Djati.

Wachidah, Nuzul. (2012). Analisis Tipologi dan Stratrgi Pengembangan Desa-desa Pesisir Kabupaten Kendal. Skripsi. Surakarta. Universitas Sebelas Maret. 